Eur J Clin Chem Clin Biochem

1995; 33:711-714

(c) 1995 Walter de Gruyter \& Co.

Berlin $\cdot$ New York

\title{
Inhibitory and Disruptive Effects of Some Antirheumatics on Antigen-Antibody Complexes
}

\author{
By Ekkehard Kallee, Uta Eistert and Richard Wahl \\ Medizinische Universitätsklinik \& Poliklinik, Isotopenlabor, Tübingen, Germany
}

(Received November 4, 1994/June 1, 1995)

To the memory of Dr. Dr. h. c. mult. Adolf Budenandt

Summary: Purified antibodies to human serum albumin or to human $\gamma$-globulin were used to study the direct influence of some antirheumatic drugs on the formation and disruption of immunoprecipitates. ${ }^{125}$ I-labelled human serum albumin and ${ }^{125}$ I-labelled human IgG served as indicators. The effects of the following drugs were described: diclofenac, monophenylbutazone, diphenylbutazone, ibuprofen, and metamizol. At approximately therapeutic concentrations, the antirheumatics inhibited the formation of complexes of homologous antibodies with human serum albumin and, surprisingly, with human IgG. When the antigens were precipitated with antibodies, subsequent addition of the antirheumatics to the preformed immunoprecipitates caused disruption of $\left[{ }^{125}\right.$ I] human serum albuminanti-human serum albumin precipitates but practically no disruption of human [ $\left.{ }^{125} \mathrm{I}\right] \mathrm{IgG}$-anti-human IgG precipitates. These new findings may be of relevance for clinical diagnosis and therapy as well as for research in immunochemistry. It is conceivable that, in patients, antirheumatic or other drugs might interfere with immunological determinations of clinico-chemical quantities. Interference of drugs with antigen-antibody reactions might also help to explain some beneficial effects or undesirable side effects of certain drugs.

\section{Introduction}

Using a special radioimmunological technique (1) for experiments on the dye-binding capacity of traces of human serum albumin in a case of Bennhold's analbuminaemia $(2,3)$ and in normal subjects, it was incidentally observed that bromophenol blue, in amounts exceeding 15-20 mol per mol human serum albumin, could release increasing amounts of ${ }^{125}$ I-labelled human serum albumin from albumin-anti-albumin immunoprecipitates. At extremely high bromophenol blue concentrations, the precipitates were practically completely dissolved. Anionic antirheumatic, analgetic and antipyretic drugs and other substances, some of which are known for their competitive properties (4-7), were therefore tested in this system. These drugs were compared with other substances selected at random.

\section{Materials and Methods}

Preparation of antibodies

Female rabbits weighing 3-4 kg were hyperimmunized to either human serum albumin (high purity grade, Behringwerke, Marburg/ Germany) or human serum $\gamma$-globulin (Beriglobin ${ }^{\circledR}$, Behringwerke, Marburg/Germany) using, in principle, a method described previously (1). The rabbits received, partly iv and partly sc, increasing doses of either human serum albumin or human IgG every second day, starting from $7 \mathrm{mg}$ and increasing to $42 \mathrm{mg}$ within 23 days; $10 \mathrm{mg}$ were administered on the 25th day, and the rabbits were bled on the 27 th or 28 th day.

The rabbit IgG was obtained by fractional precipitation with ammonium sulphate, descending from 40 percent to 35 percent saturation, followed by purification with $7 \mathrm{mmol} / \mathrm{h}(2.5$ g/l) ethacridin lactate (Rivanol ${ }^{\circledR}$, Chinosolfabrik, Seelze/Germany). The ethacridin was removed with $0.85 \mathrm{~mol} / \mathrm{l}(50 \mathrm{~g} / \mathrm{l})$ $\mathrm{NaCl}$. After dialysis of the supernatant against phosphatebuffered saline, the rabbit IgG was again precipitated, together with the ethacridin residues, at 40 percent ammonium sulphate saturation, then dissolved in water, dialysed against $1: 9$ diluted phosphate-buffered saline, and finally lyophilized. The dried rabbit IgG was dissolved in water to give $10-20 \mathrm{~g} / \mathrm{l}$ rabbit $\operatorname{lgG}$ solutions. 
125 I-labelled human serum albumin was obtained from Amersham/Buchler (Braunschweig, Germany). Highly purified human IgG (Behringwerke, Marburg, Germany) was labelled according to the method of Hunter \& Greenwood (10). For radioiodination of $20 \mu \mathrm{g}$ of human IgG in $1.5 \mathrm{ml}$ phosphate-buffered saline, $25.5 \mathrm{MBq}{ }^{125} \mathrm{I}$ and $0.5 \mathrm{mg}$ chloramine- $\mathrm{T}$ were used.

\section{Inhibition and disruption experiments}

In general, stock solutions (from commercial ampules or from preparations of pure substances) of the drugs were diluted $1: 30$ (or in some cases, $1: 25,1: 100,1: 1000$, and $1: 2000$ ) with phosphate-buffered saline. Almost all experiments were run in triplicate, a few others in duplicate.

For determination of the antigen-antibody titre, constant volumes of $100 \mu \mathrm{l}$ of the antibody solutions were mixed with different volumes of the corresponding ${ }^{125} \mathrm{I}$-labelled antigen solution. The optimal antigen volume was read from the resulting Heidelberger precipitin curve. Immunoprecipitates with relatively loose antigen-antibody bonds were prepared by precipitation in the slight antigen excess region, i. e. at points between $80 \%$ and $45 \%$ antigen precipitation. To facilitate resuspension, the immunoprecipitates were frozen in phosphate-buffered saline at $-20^{\circ} \mathrm{C}$ and thawed before washing.

In the inhibition experiments using the anti-human serum albumin antibody \#2/93, $10 \mu \mathrm{l}{ }^{125}$ I-labelled human serum albumin solution were mixed with $25 \mu \mathrm{l}$ drug solution, then left for $15 \mathrm{~min}$ at room temperature. Subsequently $50 \mu \mathrm{l}$ anti-human serum albumin \#2/93 were added, and the tubes incubated for $15 \mathrm{~min}$ at $37^{\circ} \mathrm{C}$ and left to stand $>1 \mathrm{~h}$ at $8^{\circ} \mathrm{C}$.

For the controls, $25 \mu \mathrm{l}$ phosphate-buffered saline were substituted for the $25 \mu \mathrm{l}$ drug solution. All preparations were made up with phosphate-buffered saline pH 7.4 to a final volume of $200 \mu \mathrm{l}$ and the total radioactivity was measured in a Multigamma ${ }^{\circledR}$ counter (LKB, Turku/Finland). After centrifugation at $3000 \mathrm{~g}$ and removal of the supernatant with a pipette, the samples were again washed and measured. For calculation, the radioactivity of the control precipitates was assigned a value of $100 \%$.

For the disruption experiments, the immunoprecipitates were prepared first and the washing-out effect caused by the solubility of the immunocomplexes in phosphate-buffered saline was determined. The radioactivity of the washed precipitates was assigned a value of $100 \%$ and these precipitates served as controls.

In orientation experiments, it turned out that the disruption of the human serum albumin immunoprecipitates depended not only on the actual concentration of the drugs but also on the volume of the equimolar drug solution. After mixing $25 \mu \mathrm{l}$ drug solution with $45 \mu l$ human serum albumin solution, $50 \mu$ l of antibody solution \#2/93 were added to each sample in the centrifuge tubes. The final volume of the batches was then adjusted to $200 \mu$ l with phosphatebuffered saline. Accordingly, the actual concentration of the drugs was diluted $1: 8$ in the human serum albumin inhibition experiments. In order to obtain measurable values in the disruption experiments, however, $150 \mu \mathrm{l}$ drug solution had to be added to each preformed immunoprecipitate. Thereafter, the batches were also made up with phosphate-buffered saline to a final volume of 200 $\mu$, i. e. a dilution of only $3: 4$. Hence, both the molar amount of the drugs (mol drug/mol human serum albumin) and the actual drug concentrations were much greater than in the inhibition experiments.

\section{Results}

As figure la shows, some antirheumatic and analgetic drugs such as metamizol, monophenylbutazone, diphenylbutazone, diclofenac, and ibuprofen, at concentra- tions down to the upper micromolar therapeutic range, measurably inhibit the formation of human serum albumin-anti-human serum albumin precipitates at $\mathrm{pH} 7.4$ in phosphate-buffered saline solution $(\mathrm{NaCl}, 51 \mathrm{mmol} / \mathrm{l}$; $\left.\mathrm{Na}_{2} \mathrm{HPO}_{4}, 167 \mathrm{mmol} / \mathrm{l} ; \mathrm{KH}_{2} \mathrm{PO}_{4}, 67.5 \mathrm{mmol} / \mathrm{l}\right)$.

The inhibiting drugs also disrupt some immunoprecipitates, though in general to a much lesser extent (fig. 1b). The differences between inhibition of formation of immunoprecipitates and disruption of preformed precipitates suggest that the drug-binding sites of human serum albumin are only partly involved in the antigenantibody reaction. In addition, some drug-binding sites of the human serum albumin are not obstructed by immuno-binding sites of the homologous antibody. In the disruption experiments, the preformed immunoprecipitates were suspended in $150 \mu \mathrm{l}$ drug solution, i. e. a volume six times larger than in the inhibition experiments. The dilution of the drug solutions by the small volume of the precipitates and phosphate-buffered saline trapped therein can therefore be ignored.

As controls for the albumin-binding experiments, the same drugs (see fig. 1) were used for studies on the immunoreaction between human $\gamma$-globulin and the homologous anti- $\gamma$-globulin antibody. When the $\gamma$-globulin solution was incubated with the drugs first and the homologous antibody added thereafter, some inhibitory effects were observed (fig. 2). These effects were quite unexpected since none of the antirheumatic drugs under investigation here is known to be bound to human $\gamma$ globulin. However, when the human $\gamma$-globulin was precipitated with the homologous antibody first, followed by incubation with anti-rheumatic drugs, the disrupting effect was negligible. This suggests that the antigen was enveloped so tightly by the homologous antibody that the drugs no longer had access to the drug-binding sites or to the immunological epitopes or paratopes of either the antigen or the antibody, or both.

\section{Discussion}

The reversible, non-specific binding of numerous substances, e. g. drugs, hormones or dye-stuffs, to human serum albumin or other plasma proteins was hitherto regarded as a unique phenomenon with some significance for the passive (9) transport of such substances from the blood stream into the organs, and vice versa. The present study shows, however, that some non-specific drug binding sites of human serum albumin are identical with immunologically specific epitopes and paratopes. The inhibition by antirheumatics of antigen-antibody reactions apparently is not confined to albumin-anti-albumin precipitation, but also includes inhibition of $\gamma$-globulinanti- $\gamma$-globulin precipitation. In contrast to these find- 


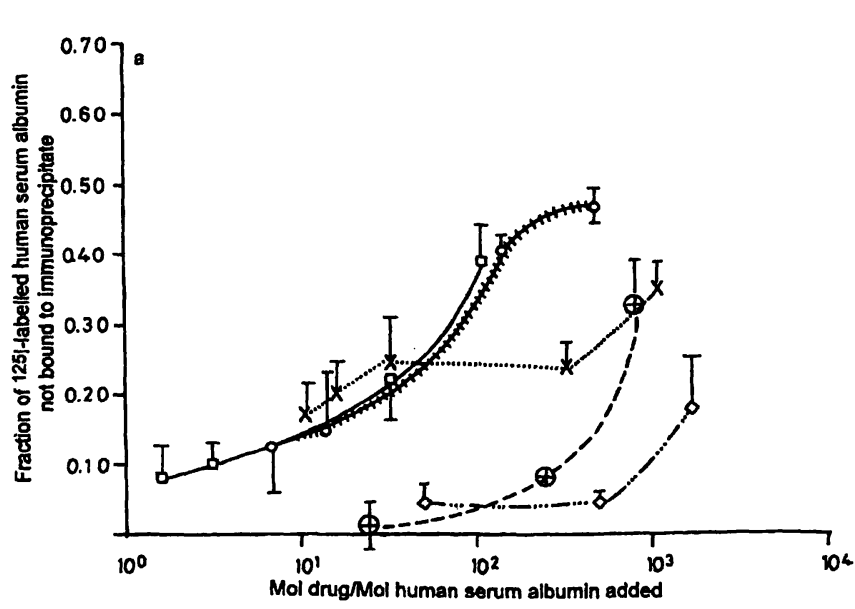

Fig. 1 Inhibiting and disrupting effects of some antirheumatic drugs on immunoprecipitation of human serum albumin.

Antigen: Mixture of $96 \%$ high purity grade human serum albumin and $4 \%{ }^{125} \mathrm{I}$-labelled human serum albumin, as indicator; $45 \mu \mathrm{g}$ of this mixture in $200 \mu \mathrm{l}$ buffer (human serum albumin $=3.4 \mu \mathrm{mol} / \mathrm{l}$ ) was placed in each centrifuge tube. Antibody: Anti-human serum albumin serum pool from rabbits, \#2/93. Each immunoprecipitate contained $66-70 \%$ of $45 \mu \mathrm{g}$ human serum albumin (= $460 \mathrm{pmol}$ ). After immunoprecipitation, the blanks without drugs contained $31.5 \mu \mathrm{g}$ human serum albumin each.

$\mathrm{T}, \perp=$ standard deviation.

ings on inhibitory effects, the disruption of preformed antigen-antibody precipitates seems essentially to be restricted to albumin-antialbumin precipitates. Thus, the bonds involved in drug adsorption are not specifically directed to drug-binding, but can also participate in immunological reactions.

Some antirheumatics other than those shown in figure 1 and 2 also disrupted immunoprecipitates or inhibited the antigen-antibody reaction, though more weakly, e.g., sodium salicylate, Aspirin ${ }^{\circledR}$ lysinate, indomethacin, piroxicam and chloroquine. Several non-antirheumatic drugs such as glibenclamid, promethazin, sodium oleate and potassium sorbate manifested similar activities.

Our findings using a radioimmunological technique cannot be directly compared with the data of Rehse \& Fiedler (8) who used ultrafiltration. Nevertheless, there is a striking parallel between the rank sequence order of the albumin binding values of Rehse \& Fiedler and our results of immuno-inhibition. For instance, these authors found particularly powerful competition values for diclofenac, ibuprofen, indomethacin and mofebutazone, whereas salicylic acid was less powerful. Common to both methods, however, are the high coefficients of variation for moṣt drugs.

For a more direct comparison of our data with those of Rehse \& Fiedler it would be necessary to calculate the apparent dissociation coefficients for both inhibition and disruption of the immunological bonds by the drugs. This will be the subject of future communications. It

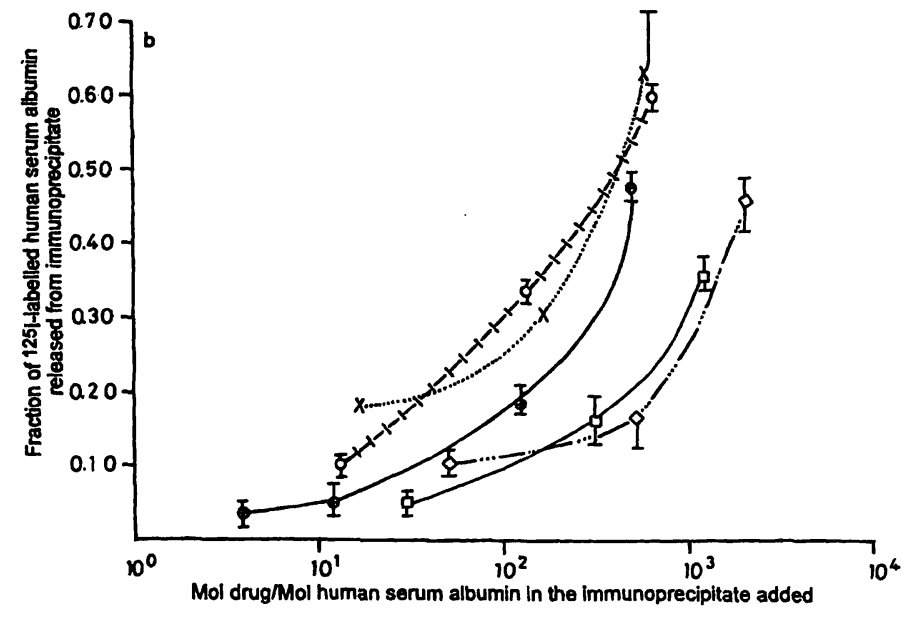

a) Drugs in $25 \mu$ phosphate-buffered saline added to human serum albumin prior to addition of antibody,

b) human serum albumin precipitated with antibody first, followed by addition of $150 \mu \mathrm{l}$ of drug solution in phosphate-buffered saline to washed precipitates. At the same drug molarities as in (a), the absolute amounts of drugs were approximately six times greater in (b) than in the inhibition experiments.

$\square \longrightarrow$ Diclofenac

O+HO Ibuprofen

X.......... Mofebutazone

$\oplus---\oplus$ Diphenylbutazone

$\diamond-\cdots \cdots-\diamond$ Metamizol

remains to be seen whether apparent coefficients obtained by entirely different methods can be directly compared.

As some preliminary experiments have shown, polyclonal antibodies from different individual animals may

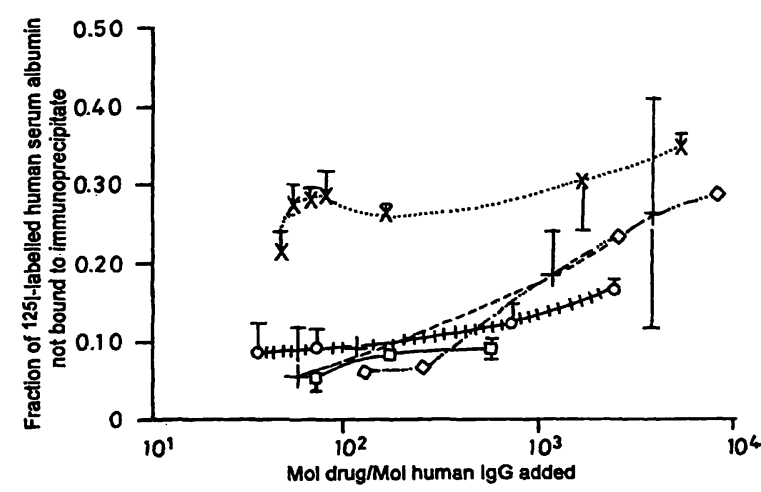

Fig. 2 Control experiments: Inhibitory effects of some antirheumatic drugs on immunoprecipitation of human serum $\gamma$-globulins. Antigen: ${ }^{125}$ I-labelled human IgG, $1.0 \mathrm{~g} / 1$ (96\% purified human IgG $+4 \%{ }^{125} \mathrm{I}$-labelled human IgG) in phosphate-buffered saline; $20 \mu \mathrm{l}$ per centrifuge tube. Antibody: Anti-human IgG pool from rabbits, \#1/93, $7 \mathrm{~g} / \mathrm{l}$. Each immunoprecipitate contained $47-49 \%$ of the added $20 \mu \mathrm{g}(418 \mu \mathrm{mol} / \mathrm{l})$ human IgG. After immunoprecipitation, the blank precipitates without drugs contained $10 \mu \mathrm{g}$ each of human IgG. Drugs were added in $150 \mu \mathrm{l}$ prior to addition of antibody. After admixture of drugs, the volume was made up to $300 \mu \mathrm{l}$ with phosphate-buffered saline.

$\square$ Diclofenac

OHHO Ibuprofen

x.......... Mofebutazone

$\oplus----\oplus$ Diphenylbutazone

$\diamond \ldots . . . \diamond$ Metamizol 
lead to somewhat different resülts. It seems therefore advisable, for future investigations, to collect large pools of antisera from different rabbits rather than to use monoclonal antibodies, since the latter may not have all desired paratopes. On the other hand, the results obtained with monoclonal antibodies would probably be more reproducible.

At present, it is not clear whether the inhibitory or disrupting effects of drugs are associated with the therapeutic efficacy or with undesirable side effects. It might be speculated that the drugs investigated so far might also inhibit immunoreactions or even disrupt immuno-complexes in vivo. This would be of importance not only with regard to possible impairment of immunological diagnostic methods, but also in the therapy of immunologically conditioned diseases. This class of diseases includes, e.g. autoimmune diseases, allergic disorders and probably also Alzheimer's disease $(11,12)$ in which beneficial effects of antirheumatic drugs such as indomethacin have been recently described.

\section{References}

1. Kallee E, Lang G, Heinzel W. Neuer quantitativer immunologischer Nachweis der leicht-reversiblen Adsorption an Proteine. Acta Isotopica (CEDAM, Padova) 1963; 3:303-21.

2. Bennhold H, Peters $H$, Roth E. Über einen Fall von kompletter Analbuminämie ohne wesentliche klinische Krankheitszeichen. Verh Dtsch Ges Inn Med 1954; 60:630-4.

3. Lohss F, Kallee E. Spurennachweis von Albumin durch Analyse von Antigen-Antikörperpraezipitaten. Clin Chim Acta $1959 ; 4: 127-33$.

4. Kallee E. Zur Natur der Azorubinbindung an Serumalbumin. Hoppe-Seylers Z Physiol Chem 1952; 290:207-15.

5. Debiasi S, Marinis S, Kallee E. Verdrängung von ${ }^{131} \mathrm{~J}$-Trijodthyronin durch anionische Medikamente im Trijodthyronintest. Acta Isotopica (CEDAM, Padova) 1963; 3:41-54.

6. Wahl R, Kallee E. Einfluß verschiedener Medikamente auf die Bindung von Schilddrüsenhormonen an Lebermitochondrien. Z Naturforsch 1974; $29 \mathrm{c}: 608-17$.

7. Wahl R, Geiseler D, Kallee E. Adsorption equilibria of thyroid hormones in the liver cell. Eur J Biochem 1977; 80:25-33.

8. Rehse K, Fiedler B. Vergleichende Untersuchungen zur Bindung nichtsteroidaler Antirheumatika an Humanserumalbumin und deren Interaktion mit Phenprocoumon. Arch Pharm (Weinheim) $1989 ; 322: 241-3$.
However, some substances not used as drugs also possess inhibitory and disruptive properties, e. g. bromophenol blue, sodium oleate, potassium sorbate, or HEPES buffer $\mathrm{pH}$ 7. It may be that these substances belong to a class of "chaotropic" compounds (13) that cause inexplicable epiphenomena. Most antirhedumatic drugs, however, do not possess such chaotropic properties. In any case, use of the novel simple immunological method described here may generate new information on the properties and chemical structure of drugs and other substances, and contribute to our knowledge of immunochemical bonds.

\section{Acknowledgements}

The authors thank Mrs. Grande, Mrs. Nerz [on a temporary grant of the Farbwerke Hoechst AG], Mrs. Doerner, Mrs. Mazuw, Mr. $B i h l$ and Mr. Schweizer for valuable technical assistance, PD Dr. G. Pawelec for linguistic advice, Mrs. Erman and Mrs. Albaum for the illustrations.

9. Kallee E, Wahl R. Passive transport of thyroid hormones from extravascular space into the circulation. Horm Metab Res 1990; 22:198-9.

10. Hunter WM, Greenwood FC. Preparation of Iodine-- ${ }^{131}$ I-labelled human growth hormone of high specific activity. Nature $1962 ; 194: 495-6$.

11. Rogers J, Kirby LC, Hempelman SR, Berry DL, McGeer PL, Kaszniak AW, et al. Clinical trial of indomethacin in Alzheimer's disease. Neurology 1993; 43:1609-11.

12. Breitner JCS, Gau BA, Welsh KA, Plassman BL, McDonald $\mathrm{WM}$, Helms MJ, et al. Inverse association of anti-inflammatory treatments and Alzheimer's disease: Initial results of a cotwin control study. Neurology $1994 ; 44: 227-32$.

13. Robinson DM. The chaotropic and taxigenic properties of zwitterionic pH buffers. Naturwissenschaften 1978; 65:438.

Prof. Dr. med. E. Kallee

Med. Univ. Klinik

Otfried-Müller-Straße 10

D-72076 Tübingen

Germany 